ks. Marcin Dera ${ }^{1}$

Uniwersytet Papieski Jana Pawła II w Krakowie

\title{
Zadania kobiety w rodzinie chrześcijańskiej według św. Jana Chryzostoma
}

Określenie zadań i miejsca kobiety w rodzinie nie jest współczesnym problemem. Można powiedzieć, że zagadnienie relacji między małżonkami jest „stare jak świat”. Od pradziejów szukano odpowiedzi na pytanie: kim są mąż i żona w małżeństwie oraz jakie są ich zadania w rodzinie? Na przestrzeni tysiącleci znajdowano różne odpowiedzi. W antyku doceniano rolę mężczyzny jako głowy rodziny, pomijając - czasami zupełnie - rolę kobiety. Rodzące się chrześcijaństwo musiało skonfrontować naukę o równości wszystkich ludzi w Chrystusie z zastaną kulturą i jej spojrzeniem na rolę mężczyzny i kobiety w małżeństwie. Jedną z wielu postaci wczesnego chrześcijaństwa, która włączyła się w dyskusję na temat doceniania roli kobiety w małżeństwie, był biskup Antiochii, a później Konstantynopola - św. Jan Chryzostom. Jego poglądy wyróżniały go na tle innych ojców Kościoła. W swoich homiliach i mowach doceniał rolę kobiety nie tylko jako matki mającej zrodzić potomstwo i strażniczki ogniska domowego, ale także jako współodpowiedzialnej za kształt

1 Ks. mgr lic. Marcin Dera - urodzony w 1978 roku w Lublinie. Od 2003 roku prezbiter archidiecezji gdańskiej. W 2003 roku ukończył Uniwersytet Kardynała Stefana Wyszyńskiego w Warszawie, uzyskując tytuł magistra teologii. W 2009 roku ukończył studia na Wydziale Teologii Uniwersytetu Warmińsko-Mazurskiego w Olsztynie, uzyskując tytuł licencjata teologii. 
wychowania dzieci i mającej wpływ na kształtowanie właściwych postaw u współmałżonka.

Niniejsze opracowanie składać się będzie z trzech części. W pierwszej zostanie omówiony kontekst historyczny nauczania św. Jana Chryzostoma. W tym celu zostanie ukazane postrzeganie ról w małżeństwie w kulturze rzymskiej. Następnie będzie omówiony wpływ kultury żydowskiej na postrzeganie roli męża i żony we wczesnochrześcijańskiej rodzinie. W ostatnim paragrafie pierwszej części zostanie ukazana nauka św. Pawła na temat roli kobiety w rodzinie i społeczeństwie chrześcijańskim.

W drugiej części zostanie przedstawiony pogląd św. Jana Chryzostoma na pozycję i zadania żony i matki w rodzinie, z uwzględnieniem jej roli wychowawczej. Następnie nauczanie Złotoustego będzie skonfrontowane z nauczaniem innych ojców Kościoła, którzy mieli odmienne poglądy na rolę kobiety w rodzinie.

W opracowaniu korzystano z dzieł polskich uczonych, takich jak: Lidia Winniczuk, Oktawiusz Jurewicz, ks. Augustyn Eckmann, Piotr Szczur, Władysław Pałubicki, Jan Iluk, ks. Józef Kudasiewicz i inni.

\section{Kontekst kulturowy nauczania św. Jana Chryzostoma}

W celu dogłębnego przeanalizowania zadań stojących przed kobietą w nauczaniu Chryzostoma należy przedstawić kontekst historyczny i kulturowy postrzegania rodziny oraz małżeństwa. W tej części zostaną przedstawione pozycja i rola mężczyzny i kobiety w kulturze hebrajskiej i grecko-rzymskiej oraz wpływ, jaki wywarły wyżej wymienione kultury na nauczanie biskupa Konstantynopola.

\section{1. Życie rodzinne w Imperium Romanum}

W starożytnym Rzymie, podobnie jak w innych kulturach antycznych, panował patriarchalizm. Wpływało to oczywiście na pozycję kobiety w społeczeństwie i jej prawa, a właściwie ich brak. W klasycznej rodzinie rzymskiej głową był ojciec - pater familias. Tylko on był całkowicie niezależny, natomiast reszta rodziny pozostawała pod jego władzą - alieno 
iuri subiecti. Ojciec miał potrójną władzę nad swoją rodziną: nad żoną manus- zwłaszcza w kwestiach utrzymania, nad dziećmi - patria potestas i władzę nad niewolnikami - dominica potestas ${ }^{2}$. Władza ojca nad rodziną była sankcjonowana prawami i tradycją sięgającą odległych czasów. Przykładem może być dzieło Dionizosa Starożytności rzymskie, w którym napisał: „Romulus nałożył na obywateli obowiązek wychowania całego potomstwa płci męskiej oraz córek pierworodnych, zabraniając pozbawienia życia dzieci przed ukończeniem lat 3, z wyjątkiem zabicia natychmiast po urodzeniu kalek i potworków" ${ }^{3}$. Jak wynika z powyższego fragmentu, władza ojca nad życiem i śmiercią dzieci została w pewien sposób ograniczona. Mimo to córki były w gorszym położeniu, bo zakaz porzucania dotyczył tylko tych, które były pierworodne.

W czasach republikańskich sytuacja nieznacznie się zmieniła. Nie uchylono prawa porzucania dzieci, ale mimo to ojcowie mieli nieco większe prawa odnośnie do swoich potomków. Mogli wyrzekać się i wydziedziczać niegodnych synów i córki ${ }^{4}$.

W codziennym życiu rodziny można było zauważyć wyraźne rozgraniczenie ról męża i żony. Kobiety, mimo że nie uczestniczyły aktywnie w życiu społeczeństwa i zarządzaniu państwem, potrafiły przeforsować swoje postulaty i wykorzystywać mężów do załatwienia swoich spraw. Przykładem może być mianowanie Gessiusa Florusa na prokuratora Judei dzięki staraniom jego żony u przyjaciółki cesarzowej Poppei czy też załatwienie przez kapłankę Kampię Sewerynę miejsca w senacie dla bliżej nieznanego Rzymianina ${ }^{5}$.

$\mathrm{Na}$ pewnego rodzaju równość w małżeństwie zwraca uwagę w formie wyrzutu senator Kanton podczas oblężenia senatu przez Rzymianki domagające się zniesienia prawa skromnego stroju ${ }^{6}$. W swoim przemówieniu wyrzucał senatorom, że nie potrafią zapanować nad swoimi żonami. Dla Kantona hańbą było przeciskanie się przez tłum niezado-

2 Por. A. Eckmann, Starożytna rodzina grecka i rzymska, „Vox Patrum” 5 (1985) z. 8-9, s. 36.

3 Cyt. za: A. Eckmann, Starożytna rodzina grecka i rzymska, dz. cyt., s. 37-38.

4 Por. A. Eckmann, Starożytna rodzina grecka i rzymska, dz. cyt., s. 38.

5 Por. O. Jurewicz, L. Winniczuk, Starożytni Grecy i Rzymianie w życiu prywatnym i państwowym, Warszawa 1968, s. 13.

6 Zob. O. Jurewicz, L. Winniczuk, Starożytni Grecy i Rzymianie..., dz. cyt., s. 13. 
wolonych kobiet rzymskich. Konsul przestrzegał senatorów przed zbytnim pobłażaniem kobietom i dawaniem im coraz większej swobody ${ }^{7}$. Sytuacja opisana przez kronikarza dowodzi, że w Rzymie kobiety zyskiwały coraz więcej praw. Było to po części spowodowane rosnącym znaczeniem kobiet $\mathrm{w}$ rodzinach.

Rzymianie potrafili docenić wierną i oddaną żonę i traktować ją z wielkim szacunkiem. W antycznej literaturze rzymskiej można znaleźć opisy wiernych swoim mężom kobiet. Przykładem jest historia Turii - bohaterskiej żony poświęcającej się ratowaniu męża ${ }^{8}$. Bohaterka tej historii żyła w czasie wojny domowej w Rzymie. Po stracie rodziców zamieszkała u przyszłych teściów ${ }^{9}$. Po wyjściu za mąż okazało się, że jej mąż był zaangażowany w wojnę po stronie przegranych. Musiał udać się na wygnanie. Turia nie porzuciła swego męża, ale poświęcała wszystkie siły, by uzyskać dla niego ułaskawienie. Przetrwała pochwała, której udzielił jej mąż: „Udzieliłaś mi w czasie ucieczki najszerzej pojętej pomocy, zrozumiałaś moje potrzeby, kiedy to przekazałaś mi całe złoto i perły, zdarłszy je wręcz ze swego ciała. Zaraz potem podstępnie oszukawszy straże moich przeciwników, wysłałaś do mnie służbę, pieniądze i pożywienie"10.

Turia prosiła samego Cezara Augusta o łaskę w sprawie męża. Potwierdza to dalsza część pochwały: „Słusznie Cezar nie chciał w swoim edykcie wspomnieć nawet słowem, że zostałem przez niego przywrócony ojczyźnie, albowiem gdybyś ty nie uczyniła tego wszystkiego, na co on miał zwrócić uwagę, nadaremnie obiecywałby swoje poparcie, strze-

7 „Zastanówcie się, jakimi to prawami przodkowie nasi ograniczyli swobodę kobiet, uzależniając je od mężów. A jednak, chociaż istnieją te wszystkie ustawy, które krępują kobiety, z trudem możecie utrzymać władzę nad nimi. Więc jakże możecie wierzyć w to, że jeżeli dopuścicie się tego, żeby stopniowo zyskiwały równouprawnienie z mężczyznami, będziecie mogli utrzymać nad nimi władzę? Przecież skoro tylko staną się nam równe, natychmiast wezmą nad nami górę" (cyt. za: O. Jurewicz, L. Winniczuk, Starożytni Grecy i Rzymianie..., dz. cyt., s. 14).

8 Por. A. Kałabun, Turia rzymskim symbolem miłości i wierności małżeńskiej, „Vox Patrum” 5 (1985) z. 8-9, s. 75.

9 Por. A. Kałabun, Turia rzymskim symbolem miłości..., dz. cyt., s. 77.

10 Cyt. za: A. Kałabun, Turia rzymskim symbolem miłości..., dz. cyt., s. 77. 
gąc mojego bezpieczeństwa. Tak więc nie mniej twojemu oddaniu niż Cezarowi to zawdzięczam"11.

Turia ostatecznie przypłaciła wstawiennictwo we władzach zdrowiem, do tego stopnia, że nie mogła mieć dzieci. Kiedy mąż powrócił do domu, chciała oddać mu majątek i odejść, aby mógł poślubić inną kobietę, z którą miałby dziecko. Reakcja męża mogła zaskoczyć jemu współczesnych: „Muszę wyznać, że do tego stopnia to mnie oburzyło, że omal nie oszalałem. Tak bardzo przeraziłem się twoich zamierzeń, że z trudem doszedłem do siebie. Mam mówić o naszym rozwodzie, jeszcze przed głosem przeznaczenia, i wyobrażać sobie, dlaczego ty żywa masz przestać być dla mnie żoną, skoro pozostałaś najwierniejszą, gdy ja byłem prawie pozbawiony życia"12.

Kwintus Lukrecjusz Wespillon - mąż Turii - nie tylko odrzucił propozycję żony, ale wychwalał jej poświęcenie i zalety pani domu, takie jak: wstydliwość, grzeczność, oddanie, przystępność, skromny ubiór, spokojny tryb życia, prawdziwa pobożność i przędzenie wełny ${ }^{13}$. Cechy wymienione przez Rzymianina dowodzą wielkiego szacunku, jaki miał względem swojej żony. Należy zauważyć, że Turia prezentowała postawę typowej Rzymianki. Kiedy nie mogła wypełnić swojego zadania - którym było zrodzenie dzieci - sama zachęcała męża do rozwodu. Takie postępowanie zachwalał w Zaleceniach małżeńskich pisarz Plutarch ${ }^{14}$.

Z powyższego tekstu wynika, że dobra Rzymianka odznaczała się skromnością i cichym towarzyszeniem mężowi w codziennym życiu. Nie oznacza to, że była wykluczona z decydowania o rodzinie czy przyszłości swojej lub nawet męża. Kobiety wywodzące się z wpływowych rodów potrafiły - mimo formalnego wykluczenia z życia politycznego - przeforsowywać swoje sprawy. W znacznie gorszej sytuacji były kobiety wywodzące się z plebsu. Nie miały one pieniędzy i wpływów, by móc cokolwiek załatwić na forum publicznym.

\footnotetext{
Cyt za: A. Kałabun, Turia rzymskim symbolem miłości..., dz. cyt., s. 78.

Cyt. za: A. Kałabun, Turia rzymskim symbolem miłości..., dz. cyt., s. 79.

Por. A. Kałabun, Turia rzymskim symbolem miłości..., dz. cyt., s. 79.

Zob. L. Winniczuk, Kobiety świata antycznego, Warszawa 1973, s. 248.
} 
Rola kobiety i małżonki w antycznym Rzymie podlegała powolnej ewolucji. W najdawniejszych czasach nie różniła się znacznie od tej w kulturze greckiej - gdzie kobieta miała niewiele więcej praw niż niewolnicy. W miarę upływu czasu i rozszerzania się granic jej rola również nabierała nowego wymiaru. Stała się opiekunką ogniska domowego i potrafiła wpływać na decyzje podejmowane przez męża.

\subsection{Wpływ judaizmu na postrzeganie ról w małżeństwie w okresie starożytności chrześcijańskiej}

Żydzi postrzegali małżeństwo zupełnie inaczej niż Grecy czy Rzymianie. od najdawniejszych czasów powszechne było wielożeństwo, poliginia, a liczba żon uzależniona była od statusu majątkowego mężczyzny. Już w Księdze Rodzaju można zauważyć ten zwyczaj: „Lamek wziął sobie dwie żony. Imię jednej było Ada, a drugiej - Silla” (Rdz 4, 19). Wśród patriarchów izraelskich wielożeństwo było normą. Pałubicki podaje, że „również w opowiadaniach o patriarchach przyjmuje się biginię jako rzecz naturalną, niewzbudzającą sprzeciwu otoczenia"15.

Z czasem poliginia stała się normą życia rodzinnego, zwłaszcza ludzi bogatych i wpływowych. W efekcie dużej liczby żon domy rozrosły się w haremy. Należy zauważyć, że nie były one wynalazkiem Izraelitów, ale zwyczajem przejętym od ludów ościennych. Współcześni badacze nie są pewni, od kiedy istnieje instytucja haremu. Pewne wskazówki są zawarte w dokumentach z drugiego tysiąclecia przed Chrystusem. Były to instrukcje władców dawane nadzorcom pałaców. Wiele z nich odnosi się do kobiet w haremach ${ }^{16}$.

Sytuacja kobiet w haremach odzwierciedlała ich pozycję społeczną. Były odizolowane od społeczeństwa, zgromadzone w jednym miejscu wraz z eunuchami i dziewczętami do posług. Obowiązywał bardzo ścisły protokół zachowania się służby i eunuchów wobec kobiet w haremie ${ }^{17}$.

15 W. Pałubicki, J. Iluk, Małżeństwo i rodzina w dawnym judaizmie i starożytnym chrześcijaństwie, Gdańsk 1995, s. 54.

16 Por. W. Pałubicki, J. Iluk, Małżeństwo i rodzina w dawnym judaizmie..., dz. cyt., s. 55.

17 Pałubicki podaje przykład takiego protokołu: „dworzanie i eunuchowie nie mogli się zbliżać do kobiety dworskiej na odległość bliższą niż siedem kroków. Nawet podsłuchiwa- 
Panowała tam nierówność, wynikająca z faworyzowania przez władców konkretnych żon. Często małżonki lubiane miały lepsze miejsca w domu kobiet. Przykładem takiego traktowania może być Estera, wyróżniona przez króla: „Dziewczyna mu się spodobała i pozyskała sobie jego życzliwość. Udał się do niej z kosmetykami i z [należną jej] częścią [utrzymania]. Dał jej też siedem dziewcząt z domu króla za towarzyszki i przeniósł ją i jej dziewczęta do lepszego miejsca w domu kobiet" (Est 2, 9).

Wielożeństwo było zarezerwowane dla królów i bogatych właścicieli ziemskich z powodów ekonomicznych. Liczne żony należało utrzymać na odpowiednim poziomie życia. Nie wszyscy mieszkańcy Izraela mogli sobie na to pozwolić. Dlatego obok poliginii istniała monogamia. Ta forma życia rodzinnego istniała w Izraelu już w czasach patriarchów (zob. Rdz 12, 5; 24, 66; 25, 20).

Obie formy małżeństwa istniały równolegle do czasów niewoli babilońskiej. Wtedy „na skutek przemian politycznych (upadek monarchii) i religijnych (predominacji warstwy kapłańskiej) ulegają również powolnym zmianom formy życia małżeńskiego"18. Władca Izraela - arcykapłan mógł, zgodnie z Prawem, poślubić dziewicę: „Za żonę weźmie tylko dziewicę. Nie weźmie za żonę ani wdowy, ani rozwódki, ani pohańbionej, ani nierządnicy: żadnej z takich nie weźmie, ale weźmie dziewicę spośród swych krewnych" (Kpł 21, 13-14). Czas niewoli babilońskiej był przełomem w postrzeganiu małżeństwa. Zanikały haremy i poliginia na rzecz monogamii, która zaczęła być traktowana jako norma życia rodzinnego. Wyjątkowe znaczenie małżeństwa monogamicznego zostało dowartościowane w wielu miejscach Pisma Świętego (zob. Ps 128, 3; Koh 9, 9; Syr $26,1-2)^{19}$. Kobieta w starożytnym Izraelu nie miała równych praw z mężczyznami. Była traktowana jako gors za odmiana człowieka. Pewnym obrazem takiego traktowania jest fragment Księgi Rodzaju, w którym Lot proponuje mieszkańcom Sodomy swoje córki ${ }^{20}$.

nie kłótni w haremie było karane ucięciem ucha i wymierzeniem stu batów" (W. Pałubicki, J. Iluk, Małżeństwo i rodzina w dawnym judaizmie..., dz. cyt., s. 60).

18 W. Pałubicki, J. Iluk, Małżeństwo i rodzina $w$ dawnym judaizmie..., dz. cyt., s. 64.

19 Por. W. Pałubicki, J. Iluk, Małżeństwo i rodzina w dawnym judaizmie..., dz. cyt., s. 64-65.

20 Zob. Rdz 19, 8. 
Zadaniem żony była głównie praca w domu. Pismo Święte ukazuje wzór kobiety pracowitej, posłusznej ${ }^{21}$. Autor biblijny ukazuje obraz żony jako tej, która stara się o dom. Pracując własnymi rękami, mogła dysponować zarobionymi pieniędzmi, co wyróżniało jej pozycję w stosunku do innych kultur starożytnych ${ }^{22}$. Jej praca nie pozostaje bezowocna, ponieważ wpływa na stanowisko męża w społeczeństwie (Por. Prz 31, 23). Wzorowa małżonka jest mądra i cicha, za co cieszy się szacunkiem domowników (Por. Prz 31, 26-29). Dobra żona jest również skromna i nie przesadza z ozdobami (Por. Iz 3, 16-24) ${ }^{23}$. Brak wyżej wymienionych cech był mocno piętnowany przez autorów biblijnych ${ }^{24}$.

Relacje rodzinne w starożytnym judaizmie nacechowane były absolutną dominacją mężczyzn. Taki stan rzeczy tłumaczono, powołując się na fragment Księgi Rodzaju, w którym Bóg, karząc za grzech pierworodny, „do niewiasty powiedział: «Obarczę cię niezmiernie wielkim trudem twej brzemienności, w bólu będziesz rodziła dzieci, ku twemu mężowi będziesz kierowała swe pragnienia, on zaś będzie panował nad tobą»" (Rdz 3, 16).

Postrzeganie i rola kobiety w judaizmie oddziaływały na wczesne chrześcijaństwo. Spowodowane to było podobną interpretacją tekstów Biblii. Paweł Apostoł nauczał, że kobieta ma być poddana mężowi (Por. 1 Kor 11,3). Takie podejście spowodowało, że życie i podział ról w rodzinie nie różniły się znacznie od tradycji judaistycznej i rzymskiej.

Wraz z kształtowaniem się doktryny chrześcijańskiej kształtowało się również spojrzenie na cel i wartość małżeństwa. Pierwszymi wyznawcami Chrystusa targały sprzeczne uczucia dotyczące znaczenia i praktyki wspólnego życia w rodzinie. Było to spowodowane słowami Pawła Apostoła: „Uważam, iż przy obecnych utrapieniach dobrze jest tak zostać, dobrze to dla człowieka tak żyć. Jesteś związany z żoną? Nie usiłuj odłączać się od niej! Jesteś wolny? Nie szukaj żony! Ale jeżeli się ożenisz, nie grzeszysz. Podobnie i dziewica, jeśli wychodzi za mąż, nie grzeszy. Tacy jednak cierpieć będą udręki w ciele, a ja chciałbym ich wam oszczędzić.

21 Zob. Prz 31, 10-22.

22 Por. E. Szymanek, Wykład Pisma św. Nowego Testamentu, Poznań 1990, s. 18.

23 Por. W. Pałubicki, J. Iluk, Małżeństwo i rodzina $w$ dawnym judaizmie..., dz. cyt., s. 69-70.

24 Por. W. Pałubicki, J. Iluk, Małżenstwo i rodzina w dawnym judaizmie..., dz. cyt., s. 70. 
Mówię, bracia, czas jest krótki. Trzeba więc, aby ci, którzy mają żony, tak żyli, jakby byli nieżonaci" (1 Kor 7, 26-29).

W niektórych kręgach małżeństwo uważano za dzieło Szatana. Nawet wśród umiarkowanych chrześcijan panował pogląd, że ci, którzy żyli ze swoim współmałżonkiem, byli na końcu kolejki zbawienia. Aby zasłużyć na życie wieczne i przypodobanie się Chrystusowi w czasie Paruzji, powstrzymywano się od współżycia ze współmałżonkiem²5.

Wielu ojców Kościoła podkreślało w jednym miejscu nierówność między kobietą a mężczyzną w życiu codziennym, a w innym równość kobiety w porządku łaski ${ }^{26}$. Przykładem takiego spojrzenia na to zagadnienie jest nauczanie Ambrożego: „Kobieta ma szanować męża, ale nie służyć mu. Niech pozwala się przezeń kierować, ale niech nie pozwala rządzić siłą brutalną. Niegodną równości małżeńskiej byłaby kobieta, która by zasługiwała na łajanie. Małżonek zaś ze swej strony powinien żonę prowadzić jako przewodnik, szanować ją jako towarzyszkę życia i pozwolić jej brać udział we wszystkim jako współdziedziczce łaski" ${ }^{27}$.

W podobnym tonie, chcąc niejako zakończyć dyskusję, wypowiada się Augustyn: „niewiasta jest stworzeniem Bożym tak jak i mężczyzna”28.

Za małżeństwo uważano związek monogamiczny. Nie można się zgodzić z tezą Pałubickiego: „Wydaje się, że również pierwotne chrześcijaństwo akceptowało poligeniczną formę małżeńską i jedynie biskupów obowiązywała monogamia"29. Z zachowanego nauczania ojców Kościoła nie wynika, by rzeczywiście tak było.

Niezwykle ważnym problemem, z którym borykał się antyczny Kościół, były pogańskie praktyki związane z uroczystościami weselnymi. Jan Chryzostom zwracał uwagę, że praktykowanie starych zabobonów jest niegodne chrześcijanina. Dał wyraz swojej dezaprobacie w dwuna-

\footnotetext{
25 Por. W. Pałubicki, J. Iluk, Małżeństwo i rodzina w dawnym judaizmie..., dz. cyt., s. 158-159.

26 Zob. W. Pałubicki, J. Iluk, Małzeństwo i rodzina w dawnym judaizmie..., dz. cyt., s. 160-164.

${ }_{27}$ Ambroży, List, 64, 107, cyt. za: W. Pałubicki, J. Iluk: Małżeństwo i rodzina w dawnym..., dz. cyt., s. 163.

28 Augustyn, O państwie Bożym, XXII, 17, za: W. Pałubicki, J. Iluk, Małżeństwo i rodzina $w$ dawnym judaizmie..., dz. cyt., s. 165.

${ }_{29}$ Zob. W. Pałubicki, J. Iluk, Małżeństwo i rodzina $w$ dawnym judaizmie..., dz.cyt., s. 66. Autorzy nie podają tu żadnych argumentów na podtrzymanie swojej tezy.
} 
stej Homilii na I List św. Pawła do Koryntian: „Małżeństwo uważane jest za dzieło godne uszanowania zarówno u nas, jak też i u pogan; i w rzeczywistości jest ono zaszczytne, lecz podczas zawierania małżeństw czyni się wiele rzeczy śmiesznych, jak o tym zaraz usłyszycie. Wielu naśladując zwyczaj i wprowadzając się w błąd fałszywym rozumowaniem, nawet nie rozpoznaje niedorzeczności tego wszystkiego i próbuje jeszcze szukać pouczeń od innych. Są tu [na weselach] tańce i cymbały, flety i bezwstydne mowy, niegodziwe piosenki, pijaństwo, nieprzyzwoite żarty i wszelkie diabelskie śmieci" ${ }^{30}$. Wielu spośród słuchaczy zarzucało Złotoustemu, że piętnując nadużycia w czasie wesel, występuje przeciwko małżeństwu jako takiemu. Kaznodzieja bronił się, stwierdzając, że nie jest przeciwny małżeństwu, ale pewnym praktykom, takim jak wystawne przyjęcia, przesadne używanie biżuterii i kosmetyków ${ }^{31}$. Dla Chryzostoma pogańskie praktyki, jakie stosowano podczas ceremonii zaślubin, godziły w świętość małżeństwa chrześcijan. Złotousty zdawał sobie sprawę, że potępianie zakorzenionych praktyk nie przyniesie mu poklasku wiernych: „Wiem, że jestem przykry, nieznośny i natarczywy, chcąc usunąć z życia tę przyjemność" ${ }^{32}$. Nie przejmował się opinią wiernych, ponieważ dbał o ich dobro duchowe.

W przygotowaniu do małżeństwa nikt nie mówił o miłości. Bazując na dostępnej literaturze, można stwierdzić, że były to związki zawierane z szeroko pojętego ro zs ą dku. Na takim modelu podejścia do spraw rodziny wczesne chrześcijaństwo budowało własny obraz małżeństwa.

\subsection{Wpływ św. Pawła na nauczanie św. Jana Chryzostoma o kobiecie}

Przedstawione wyżej podejście kultury pogańskiej i judaizmu do kwestii małżeństwa znalazło odzwierciedlenie w sposobie postrzegania ról w rodzinie przez Pawła z Tarsu. W swoich listach z jednej strony podkreślał równość kobiety i mężczyzny w porządku łaski Bożej ${ }^{33}$, a z innej pod-

30 Cyt. za: P. Szczur, Problematyka społeczna w późnoantycznej Antiochii: na podstawie nauczania homiletycznego Jana Chryzostoma, Lublin 2008, s. 308.

31 Por. P. Szczur, Problematyka społeczna w późnoantycznej Antiochii..., dz.cyt., s. 308.

32 Cyt. za: P. Szczur, Problematyka społeczna w późnoantycznej Antiochii..., dz. cyt., s. 309.

33 Zob. 1 Kor 11, 11-12; Ga 3, 28. 
danie żony mężowi - jako głowie rodziny ${ }^{34}$. Paweł Apostoł, opisując relacje w małżeństwie, sięga do wzorców znanych w starożytności, takich jak poddaństwo żony czy posłuszeństwo domowników ojcu rodziny ${ }^{35}$. To odpowiadało poglądom Rzymian, którzy uważali, że mężczyzna powinien panować, a obowiązkiem żony jest posłuszeństwo mężowi ${ }^{36}$. Ten pogląd znajduje swoje odzwierciedlenie w zakazie przemawiania na zgromadzeniach przez kobiety: „Nauczać zaś kobiecie nie pozwalam ani też przewodzić nad mężem, lecz [chcę, by] trwała w cichości” (1 Tm 2,12).

Problem z określeniem roli kobiety w rodzinie, wspólnocie wierzących i społeczeństwie wynikał z zastanych norm kulturowych. W czasie działalności Pawła z Tarsu niewiasty miały duże znaczenie w gminach chrześcijańskich ${ }^{37}$. Dzieje Apostolskie podają, że w gminach chrześcijańskich funkcjonowały kobiety - prorokinie: „Wyszedłszy nazajutrz, dotarliśmy do Cezarei. Weszliśmy do domu Filipa ewangelisty, który był jednym z Siedmiu, i zamieszkaliśmy u niego. Miał on cztery córki, dziewice mające dar proroctwa" (Dz 21, 8-9)38. Działalność dziewic - prorokiń wywoływała problemy z chrześcijanami wywodzącymi się z judaizmu, którzy nakłaniali współbraci pochodzących z pogaństwa do zachowywania norm Prawa Mojżeszowego ${ }^{39}$. Ewentualne przyjęcie przez młody Kościół zasad judaizmu wywołałoby wycofanie kobiet z misji ewangelizacyjnej. Paweł bardzo stanowczo przeciwdziałał prądom judeochrześcijańskim, przypominając, że wszyscy ludzie ochrzczeni w Chrystusie są sobie równi ${ }^{40}$, oraz ostro występując przeciwko tym, którzy zmuszali braci pochodzenia pogańskiego do zachowywania zwyczajów żydowskich: „Nadziwić się nie mogę, że od Tego, który was łaską Chrystusa powołał, tak szybko

34 Zob. 1 Kor 11, 3; 1 Tm 2, 11. 13; Ef 5, 22-24; Kol 3, 18.

35 Por. J. Kudasiewicz, Mężowie miłujcie żony, jak Chrystus umiłował Kościót (Ef 5, 21-33), „,Vox Patrum" 5 (1985) z. 8-9, s. 82.

36 Por. J. Kudasiewicz, Mężowie miłujcie żony..., dz. cyt., s. 86.

37 Por. J. Klinkowski, Kobiety biblijne w życiu społeczno-religijnym na tle starożytnej kultury, Legnica 2016, s. 65.

38 Zob. J. Vinatier, Kobieta w Kościele, przeł. K. Wróblewska, Warszawa 1976, s. 48-49.

39 Por. J. Klinkowski, Kobiety biblijne w życiu społeczno-religijnym na tle starożytnej kultury, dz. cyt., s. 66.

${ }_{40}$ Zob. J. Klinkowski, Kobiety biblijne w życiu społeczno-religijnym na tle starożytnej kultury, dz. cyt., s. 66 . 
chcecie przejść do innej Ewangelii. Innej jednak Ewangelii nie ma: są tylko jacyś ludzie, którzy sieją wśród was zamęt i którzy chcieliby przekręcić Ewangelię Chrystusową. Ale gdybyśmy nawet my lub anioł z nieba głosił wam Ewangelię różną od tej, którą wam głosiliśmy - niech będzie przeklęty! Już to przedtem powiedzieliśmy, a teraz jeszcze mówię: Gdyby wam ktoś głosił Ewangelię różną od tej, którą [od nas] otrzymaliście - niech będzie przeklęty!” (Ga 1, 6-9). Paweł z Tarsu w swoich listach i nauczaniu opisanym w Dziejach Apostolskich wyraźnie odcina kulturę judaizmu od rozwijającego się chrześcijaństwa ${ }^{41}$. Próbował - wbrew panującej kulturze - docenić rolę kobiety. W tym celu korzystał w swojej działalności z pomocy niewiast, do czego się przyznaje w Liście do Koryntian: „Czyż nie wolno nam brać ze sobą niewiasty-siostry, podobnie jak to czynią pozostali apostołowie oraz bracia Pańscy i Kefas?" (1 Kor 9, 5) ${ }^{42}$. Bardzo serdecznie wypowiadał się również o niewiastach zaangażowanych w gminach chrześcijańskich ${ }^{43}$. Można powiedzieć, że wbrew oskarżeniom św. Pawła o wrogość wobec kobiet ${ }^{44}$ Apostoł Narodów darzył je szacunkiem i doceniał ich pracę dla gminy chrześcijańskiej. Krytyczne wypowiedzi można tłumaczyć jako próbę pogodzenia tradycji z nową rolą niewiasty, która w Chrystusie stałą się si o strą mężczyzny.

Mimo znacznych ograniczeń kulturowych kobiety odegrały znaczną rolę w Kościele w czasach św. Pawła z Tarsu. Niestety wpływ gnozy i bardzo silne oddziaływanie kultury grecko-rzymskiej spowodowały, że w kolejnych wiekach rola kobiety w Kościele bardzo osłabła i przypominała wyniesioną z judaizmu wizję żony podporządkowanej we wszystkim mężowi ${ }^{45}$. Zmianę nastawienia do niewiast można zauważyć u św. Polikarpa, który w Liście do Filipian, napisanym około 110 roku po Chr., chciał ograniczyć działalność kobiety w gminie, określając jej

41 Zob. Ga 2, 14-16.

42 Por. J. Vinatier, Kobieta w Kościele, dz. cyt., s. 49.

43 Zob. Rz 16, 1-3. 6. 12. 15; por. J. Vinatier, Kobieta w Kościele, dz. cyt., s. 50.

44 Zob. J. Vinatier, Kobieta w Kościele, dz.cyt., s. 49. Również w praktyce duszpasterskiej dotyczącej przygotowania do sakramentu małżeństwa można spotkać się ze strony młodych ludzi - zwłaszcza kobiet - z twierdzeniem, że św. Paweł był wrogiem niewiast.

45 Por. J. Klinkowski, Kobiety biblijne w życiu społeczno-religijnym na tle starożytnej kultury, dz. cyt., s. 68. 
rolę jako dziewicy - zawsze wiernej żony i bogobojnej wdowy. Podobnie wypowiadał się Tertulian ${ }^{46}$.

Święty Paweł Apostoł wywodził się z bardzo konserwatywnej grupy faryzeuszów. Pochodzenie i odebrane wykształcenie nie przeszkodziły mu w docenieniu roli kobiety w Kościele. Krytyczne wypowiedzi dotyczące działalności niewiast w gminach chrześcijańskich wynikały z troski o porządek i szacunku do tradycji judaizmu i kultury grecko-rzymskiej ${ }^{47}$. Niestety następcy św. Pawła powrócili do wizji niewiasty jako cichej odbiorczyni słowa Bożego, wzorowej żony, bogobojnej dziewicy lub wdowy, która miała milczeć w Kościele.

\section{Kobieta jako żona i matka}

W tej części zostaną przedstawione poglądy Złotoustego na temat roli kobiety jako żony i matki. Opisując zadania i rolę kobiety w małżeństwie, często odnosił się do Pisma Świętego, szczególnie do pism św. Pawła.

Według nauczania Złotoustego zawartego w Homilii na Księgę Rodzaju małżonka miała być pomocą dla mężczyzny przez swoją cnotliwość. Prawdziwie chrześcijański dom był miejscem spokoju i oderwania od rzeczy światowych ${ }^{48}$. Dobra niewiasta ma być spokojna, cnotliwa, oddana swemu mężowi oraz pomagająca mu w różnych sprawach ${ }^{49}$. Ponadto dobra żona miała zabiegać o chrześcijański charakter rodziny: „Z kolei żona niech jeszcze bardziej troszczy się o to, aby cały dom spełniał uczynki prowadzące do nieba"50. Tak więc Jan Chryzostom przypominał chrześcijańskim małżonkom, że troska o religijny charakter rodziny spoczywa

46 Por. J. Klinkowski, Kobiety biblijne w życiu społeczno-religijnym na tle starożytnej kultury, dz. cyt., s. 68.

${ }^{47}$ Por. J. Klinkowski, Kobiety biblijne w życiu społeczno-religijnym na tle starożytnej kultury, dz. cyt., s. 68 .

48 Por. H. Wójtowicz, Zadania rodziny chrześcijańskiej w nauczaniu św. Jan Chryzostoma, „Vox Patrum" 5 (1985) z. 8-9 s. 210-211.

49 Por. H. Wójtowicz, Zadania rodziny chrześcijańskiej w nauczaniu św. Jan Chryzostoma, dz. cyt., s. 210-211.

50 Jan Chryzostom, Homilie na Ewangelięwedług św. Mateusza, cz. 2, Homilie 41-90, LXXXVII, 6, Kraków 2002, s. 413. 
na ojcu i matce ${ }^{51}$. Według Złotoustego oboje są wezwani do budowania prawdziwie chrześcijańskiej wspólnoty życia rodzinnego.

Bardzo ważnym zadaniem kobiety w czasach Złotoustego było wydanie na świat potomstwa. Święty Jan Chryzostom zdawał sobie sprawę z podejścia kultury antycznej do prokreacji. Za jego życia nadal panowało przekonanie, że brak potomstwa w małżeństwie jest hańbą ${ }^{52}$. Bronił kobiet, które w antyku najczęściej obwiniano za brak potomstwa, stwierdzając, że starotestamentowe kobiety niemające potomstwa przygotowywały świat na przyjście Maryi Dziewicy. Pouczał mężów, by nie sprawiali przykrości żonie z powodu bezpłodności ani nie szukali potomstwa poza małżeństwem. Kobietom, które dźwigały brzemię bezdzietności, zalecał pokładanie ufności w Bogu na wzór biblijnej Anny ${ }^{53}$. Jan Chryzostom, doceniając małżeństwa bezdzietne, współczuł kobietom bezdzietnym. W XXXVIII Homilii na Księge Rodzaju stwierdził, „że nie ma dla kobiety nic trudniejszego do zniesienia niż bezpłodność" 54 .

Kobieta, która została matką, miała według Złotoustego dbać o wychowanie religijne dziecka. Jako wzór troskliwej rodzicielki wychowującej swoje dzieci przedstawił historię braci machabejskich ${ }^{55}$. Na tle epoki to była nowość. Dotychczas matka zajmowała się dziećmi - chłopcami i dziewczynkami do około 7 roku życia. Starszych synów wychowywał ojciec, posyłając ich do szkoły. Natomiast dziewczęta zostawały przy matce i uczyły się obowiązków żony i matki ${ }^{56}$.

${ }^{51}$ „Jeśli w rzeczach doczesnych staramy się spełniać obowiązki publiczne przed sprawami domowymi, aby nie karano nas z powodu ich zaniedbania, nie wleczono na rynek i nie znieważano, tym bardziej należy tak postępować w rzeczach duchowych, aby najpierw wypełniać obowiązki względem Boga - Króla niebieskiego (por. Łk 12, 29-31), abyśmy nie dostali się tam, gdzie będzie zgrzytanie zębów" (Jan Chryzostom, Homilie na Ewangelię według św. Mateusza, cz. 2, Homilie 41-90, LXXXVII, 6, s. 413).

52 Por. P. Szczur, Problematyka społeczna w późnoantycznej Antiochii: na podstawie nauczania homiletycznego Jana Chryzostoma, s. 298.

53 Por. P. Szczur, Problematyka społeczna w późnoantycznej Antiochii..., dz.cyt., s. 298.

54 Por. P. Szczur, Problematyka społeczna w późnoantycznej Antiochii..., dz.cyt., s. 298.

55 Por. P. Szczur, Problematyka społeczna w późnoantycznej Antiochii..., dz.cyt., s. 327.

56 Por. Historia wychowania, t. 1, red. Ł. Kurdybach, Warszawa 1965, s. 112. 
Niektórzy komentatorzy uważają, że wpływ na poglądy Jana Chryzostoma dotyczące roli matki w rodzinie miały doświadczenia $\mathrm{z}$ dzieciństwa ${ }^{57}$. O tych doświadczeniach można dowiedzieć się z lektury Dialogów o kapłaństwie. Złotousty opisywał, że w młodości poszukiwał przedstawień teatralnych i przyjemności cielesnych ku utrapieniu matki i jego pobożnych przyjaciół. Jeden z jego przyjaciół - Bazyli namawiał go do opuszczenia domu i życia na wzór monastyczny.

Złotousty był już zdecydowany pójść za radą przyjaciela, gdy zainterweniowała matka ${ }^{58}$. Matka Jana Chryzostoma dbała o wychowanie swojego syna, pielęgnowała jego majątek po ojcu, łożąc z pieniędzy swojej rodziny na jego wykształcenie ${ }^{59}$. Spotkanie matki z synem i wspominanie wspólnej niedoli osieroconej rodziny miało wpłynąć na zachowanie młodego Jana ${ }^{60}$. To wydarzenie wpłynęło na poglądy Jana Chryzostoma dotyczące roli matki w wychowaniu dzieci. Pokierowanie dzieckiem i wszczepienie w jego serce dobrych i pobożnych nawyków to był jej przywilej ${ }^{61}$.

Jan Chryzostom doceniał rolę kobiety - jako żony i matki. Doceniał jej wkład w życie rodzinne oraz w wychowanie dzieci. Młodym matkom stawiał za wzór pobożne niewiasty z Pisma Świętego. Zachęcał małżonków do wzajemnej troski o siebie i swoje dzieci oraz do wspierania się na drodze do świętości. Mimo że widział żonę w roli strażniczki o gn is k a do mow e go, doceniał jej równość w porządku łaski i w drodze do świętości.

\section{Relacje między kobietą a mężczyzna}

Analizując dość bogatą spuściznę homiletyczną Chryzostoma, można dojść do wniosku, że pojmował on życie rodzinne jako wspólnotę życia i miłości, która miała przeradzać się w kośc iół do mow y. Jego wizja

57 Por. W. Kania, Pierwsza rodzinna katecheza domowa w ujęciu św. Jana Chryzostoma, „Vox Patrum" 5 (1985) z. 8-9, s. 216.

58 Zob. Jan Chryzostom, Dialogi o kapłaństwie, I, 2, przekł. W. Kania, Kraków 1992, s. 44-45.

59 Por. Jan Chryzostom, Dialogi o kapłaństwie, I, 2, dz. cyt., s. 45.

60 Zob. Jan Chryzostom, Dialogi o kapłaństwie, I, 2, dz. cyt., s. 45.

61 Por. W. Kania, Pierwsza rodzinna katecheza domowa w ujęciu św. Jana Chryzostoma, dz. cyt., s. 216. 
została zaczerpnięta z nauczania św. Pawła Apostoła. Przedstawiał wiernym wzorcowy dom chrześcijański, jakim była rodzina Pryscylli i Akwili ${ }^{62}$. Jan Chryzostom nawoływał rodziny do stawania się godnymi tytułu kościoła domowego ${ }^{63}$. Nie dla wszystkich było to oczywiste. Dowodem tego jest zapisana odpowiedź Złotoustego na zarzuty pewnego ojca rodziny ${ }^{64}$. Oskarżał on Chryzostoma o nawoływanie chrześcijan do pozostawienia rodziny i udania się na pustynię, aby wieść życie anachorety. Złotousty odparł te zarzuty, stwierdzając, że nie nakłania nikogo do porzucenia rodziny, ale namawia do prawdziwie chrześcijańskiego życia. Ostrzegał, że życie w mieście niesie ze sobą zagrożenia, z których na pierwszym miejscu stawiał niemoralne widowiska teatralne ${ }^{65}$. Zagrożenia, przed którymi przestrzegał św. Jan Chryzostom, dotykały w swoich skutkach kobiety żony, które stawały się ofiarami pożądliwości mężów ${ }^{66}$. Jako przeciwwagę wobec niegodziwego traktowania żony stawiał za przykład rodzinę przyjaciół św. Pawła z Tarsu. W homilii Salutate Priscillam prawdziwie chrześcijańskie życie małżonków postawił na równi z życiem mnichów. Praca zawodowa, domowa, wychowywanie dzieci były drogą do świętości dla chrześcijan zwiazanych sakramentem małżeństwa ${ }^{67}$.

Święty Jan Chryzostom bardzo jasno wyszczegółnił rolę kobiety i mężczyzny w życiu rodzinnym. Dostrzegał nierówność, jaka panowała w pojmowaniu roli kobiety i mężczyzny w małżeństwie. Jak zostało to przedstawione wyżej, gorsza pozycja niewiasty wynikała z uwarunkowań kulturowych. Ponadto upatrywał problem w grzechu pierworodnym. To właśnie pierwszy występek prarodziców spowodował rozpad jedności i równości mężczyzny i niewiasty. Analizując związek kobiety i mężczyzny, Jan Chryzostom stwierdził, że przed grzechem pierworodnym byli

62 Zob. Jan Chryzostom, Homilie na List św. Pawła do Rzymian, t. I/2, XXX, 3, Kraków 1998, s. 442 .

63 Por. A. Bober, Rodzina kościołem domowym według św. Jana Chryzostoma, „Vox Patrum” 5 (1985) z. 8-9, s. 195.

64 Por. A. Bober, Rodzina kościołem domowym według św. Jana Chryzostoma, dz. cyt., s. 195.

${ }_{65}$ Jan Chryzostom, Homilie na Ewangelię według św. Mateusza, cz. 1, Homilie 1-40, VII, 7, Kraków 2002, s. 100-101.

${ }_{66}$ Jan Chryzostom, Homilie na Ewangelię według św. Mateusza, cz. 1, Homilie 1-40, VI, 7, dz. cyt., s. 89.

${ }^{67}$ Por. A. Bober, Rodzina kościołem domowym według św. Jana Chryzostoma, s. 196-197. 
sobie równi w godności ${ }^{68}$. Złotousty tłumaczył to, wyjaśniając fragment Księgi Rodzaju opisującej stworzenie mężczyzny i kobiety na wzór Boga. Skutkiem grzechu pierworodnego było podporządkowanie kobiety mężczyźnie ${ }^{69}$.Jan Chryzostom w ten sposób dawał do zrozumienia, że niewiasta jest poddana mężczyźnie z powodu grzechu. To podporządkowanie rzutowało na rozdział zadań pomiędzy małżonkami w małżeństwie. Rola kobiety według Złotoustego polegała na zaufaniu do męża ${ }^{70}$. Natomiast władza mężczyzny miała być miarkowana miłością do kobiety ${ }^{71}$. Jan Chryzostom, rozważając wzajemne relacje męża i żony, twierdził, że spoiwem ich związku było wzajemne pożądanie, które było dziełem Boga ${ }^{72}$.

W Homilii na Księgę Rodzaju Złotousty stwierdził, że przed nieposłuszeństwem kobieta i mężczyzna byli równi również w porządku natury ${ }^{73}$. Grzech zniszczył tę równość i doprowadził do podporządkowania kobiety. Konsekwencją tego był według Chryzostoma Pawłowy zakaz nauczania nałożony na niewiasty ${ }^{74}$. Złotousty potwierdzał naukę św. Pawła o poddaniu kobiet mężom z jednym wyjątkiem. W przypadku grzesznego męża zadaniem żony było pouczanie i nakłanianie do nawrócenia. Dał temu wyraz w jednej ze swych homilii: „Chcę was [mężowie] powierzyć waszym żonom, aby one was pouczyły. To prawda, że zgodnie z nakazem Pawła to wy powinniście być nauczycielami, skoro jednak porządek został odwrócony z powodu grzechu, ciało znalazło się na górze, głowa na dole, to podejmijmy i taką drogę"75. Ta pewnego rodzaju rewolucja w pojmowaniu roli żony jako współodpowiedzialnej za męża wynikała z podkreślania równości mężczyzny i niewiasty w porządku godności i łaski.

68 Por. Jan Chryzostom, Homilie na Księgę Rodzaju - seria pierwsza Rdz 1-3, IV, 1, Kraków 2008, s. 74.

${ }_{69}$ Zob. Jan Chryzostom, Homilie na Księgę Rodzaju - seria pierwsza Rdz 1-3, IV, 1, dz.cyt., s. 74.

70 Zob. Jan Chryzostom, Homilie na Księgę Rodzaju - seria pierwsza Rdz 1-3, IV, 1, dz. cyt., s. 75; por. J. Jurkiewicz, „Mater Familias” w nauczaniu św. Jana Chryzostoma, „Vox Patrum” 29 (2009) 53-54, s. 228.

71 Jan Chryzostom, Homilie na Księgę Rodzaju - seria pierwsza Rdz 1-3, IV, 1, dz. cyt., s. 76.

72 Jan Chryzostom, Homilie na Księgę Rodzaju - seria pierwsza Rdz 1-3, IV, 1, dz. cyt., s. 75.

73 Jan Chryzostom, Homilie na Księge Rodzaju - seria pierwsza Rdz 1-3, VI, 2, dz. cyt., s. 93.

74 Jan Chryzostom, Homilie na Księgę Rodzaju - seria pierwsza Rdz 1-3, IV, 1, dz. cyt., s. 75.

75 Jan Chryzostom, Homilie na Ewangelię według św. Mateusza, cz. 1, Homilie 1-40, VII, 6, dz, cyt., s. 99. 
Święty Jan Chryzostom pouczał swoich wiernych, że fundamentem prawdziwie chrześcijańskich relacji między małżonkami jest miłość, która przewyższa wszelkie uczucia ${ }^{76}$. Jest ona niezwykle istotna we wzajemnych relacjach między mężem i żoną ${ }^{77}$.W przypadku małżonków chrześcijańskich miłość powinna być rozwijana na wzór Chrystusa. Złotousty pouczał, że ta miłość jest trudniejsza, wymagająca więcej wysiłku i samozaparcia. Z tej miłości ma się rodzić wzajemny szacunek małżonków ${ }^{78}$. Złotousty przestrzegał przed minimalizmem. Twierdził, że pomimo trudności w sprostaniu przykładowi relacji Chrystusa i Kościoła zadaniem męża w stosunku do żony jest budowanie relacji w oparciu o miłość, która jest najsilniejszym węzłem międzyludzkim ${ }^{79}$. Dalej stwierdził, że wzór, jaki zostawił człowiekowi Zbawiciel, zobowiązuje do praktykowania miłości we wszystkich aspektach - nawet (a może przede wszystkim) poprzez cierpliwość i przebaczenie dla krnąbrnej i złośliwej żony ${ }^{80}$.

Święty Jan Chryzostom widział fundament relacji małżonków we wzajemnej miłości, która była odbiciem miłości Chrystusa do Kościoła. To z niej miały wypływać wszelkie odniesienia się małżonków do siebie. Zaskakujący jest fakt, że Złotousty pozwalał żonie pouczać męża, który pogrążał się w grzechach. Wyżej cytowane zdanie z Homilii na Ewangelię według św. Mateusza było czymś niezwykłym w czasach późnego antyku. Według Iluka ojcowie Kościoła nie byli zdecydowani w postrzeganiu kobiet i ich roli w chrześcijaństwie. Przykładowo Klemens Aleksandryjski w dziele Wychowawca tak opisywał niewiastę: „każdą kobietę powinna napawać obrzydzeniem sama myśl, że jest kobietą" ${ }^{11}$. W jeszcze ostrzejszym tonie wypowiadał się Tertulian w 0 klejnocie kobiet: „Ty jesteś drzwiami diabła, tyś zerwała pieczęcie z owego drzewa, tyś namówiła tego, którego Szatan nie zdoła zaszczepić. Tyś obraz Boga, człowieka, tak łatwo zniszczyła; dla twojej zapłaty, to jest śmierci, musiał też Syn Boga umrzeć"82. Zarówno

76 Jan Chryzostom, Homilia na List do Efezjan, 20, 1, dz. cyt., s. 47-48.

77 Jan Chryzostom, Homilia na List do Efezjan, 20, 1, dz. cyt., s. 48.

78 Jan Chryzostom, Homilia na List do Efezjan, 20, 2, dz. cyt., s. 49-50.

79 Jan Chryzostom, Homilia na List do Efezjan, 20, 2, dz. cyt., s. 50.

80 Jan Chryzostom, Homilia na List do Efezjan, 20, 2, dz. cyt., s. 50.

81 Cyt. za: W. Pałubicki, J. Iluk, Małżeństwo i rodzina w dawnym judaizmie..., dz. cyt., s. 160.

82 Cyt. za: W. Pałubicki, J. Iluk, Małżeństwo i rodzina w dawnym judaizmie..., dz. cyt., 160-161. 
Tertulian, jak i Orygenes podkreślali, że podleganie kobiety mężczyźnie pochodzi z grzechu pierworodneg ${ }^{83}$. Dowodem na postrzeganie kobiety jako istoty niższej $w$ godności od mężczyzny była wypowiedź pewnego biskupa na Synodzie w Mačon w 585 roku, podczas sesji poświęconej rozstrzygnięciu w majestacie prawa kanonicznego kwestii zbawienia kobiet. Tenże biskup stwierdził, że „kobiety nie można uważać za człowieka”" Na szczęście „po tym, jak zebrani biskupi udzielili wyjaśnienia, tenże się uspokoił"85.

Podkreślanie przez Złotoustego równości w godności i powołaniu do świętości męża i żony było niezwykłe na tle postrzegania tej problematyki przez innych ojców Kościoła. Można powiedzieć, że Chryzostom dobrze odczytał nauczanie św. Pawła Apostoła, który z jednej strony szanował tradycję, a z drugiej podkreślał równość mężczyzny i niewiasty w Chrystusie.

\section{Zakończenie}

Celem niniejszego opracowania było ukazanie roli żony jako wychowawczyni w rodzinie w nauczaniu św. Jana Chryzostoma. W epoce Złotoustego było to nowatorskie podejście. Dla wielu chrześcijan homilie biskupa Antiochii, a później Konstantynopola były szokujące. Mężczyźni, którzy wyrośli z kultury pogańskiej - wciąż obecnej w IV wieku po Chrystusie - przyzwyczaili się do postrzegania kobiety jako przekazicielki życia nowemu pokoleniu i „służącej” męża. Jan Chryzostom przeciwstawiał się takiemu postrzeganiu żony i ukazywał jej współodpowiedzialność w Chrystusie za duchowy wymiar życia rodziny.

Stosunek Chryzostoma do kobiet był z jednej strony nacechowany kulturą, w której wzrastał i żył, a która sprowadzała żonę do roli cichej towarzyszki życia mężczyzny usługującej mu po dniu jego ciężkiej pracy. $Z$ drugiej strony dostrzegał niezwykłe zadanie, jakie stało przed niewia-

\footnotetext{
83 Por. W. Pałubicki, J. Iluk, Małżeństwo i rodzina w dawnym judaizmie..., dz. cyt., s. 160.

${ }_{84}$ Grzegorz z Tour, Historia Franków, VIII, 20, za: W. Pałubicki, J. Iluk, Małżeństwo i rodzina w dawnym judaizmie..., dz. cyt., s. 165.

85 W. Pałubicki, J. Iluk, Małżeństwo i rodzina $w$ dawnym judaizmie..., dz. cyt., s. 165.
} 
stą w rodzinie - współodpowiedzialność za wychowanie współmałżonka i dzieci ${ }^{86}$. To zadanie upoważniało żonę do pouczania męża, który zszedł z drogi moralności chrześcijańskiej oraz do współodpowiedzialności za wychowanie syna. Ubolewał, że „kobiety nie wierzą, że ich zadaniem jest także zajmowanie się chłopcami, tak jak dziewczynkami”87.

Nauczanie św. Jana Chryzostoma ukazuje, że nawet w czasach panowania kultury i obyczajowości pogańskiej rozwijające się chrześcijaństwo uświadamiało niewiastom i mężczyznom, że są współodpowiedzialni za duchowy rozwój swojej rodziny i siebie nawzajem.

86 Por. J. Jurkiewicz: „Mater Familias” w nauczaniu św. Jana Chryzostoma, dz. cyt., s. 230.

87 Cyt. za J. Jurkiewicz: „Mater Familias” w nauczaniu św. Jana Chryzostoma, dz. cyt., s. 230. 


\section{Summary}

Zadania kobiety w rodzinie chrześcijańskiej według św. Jana Chryzostoma

Artykuł przedstawia stanowisko jednego z najwybitniejszych homiletów starożytności chrześcijańskiej w temacie roli kobiety w małżeństwie i rodzinie. W opracowaniu ukazano poglądy Chryzostoma, które wyróżniały go na tle innych ojców Kościoła. W pierwszej części przedstawiono kontekst kulturowy nauczania biskupa Konstantynopola. Ukazano postrzeganie roli kobiety w kulturze antycznej grecko-rzymskiej, w judaizmie oraz w nauczaniu św. Pawła z Tarsu. W drugiej części artykułu przedstawiono poglądy Chryzostoma na temat kobiety jako żony i matki. W trzeciej części opracowania ukazano relacje między kobietą i mężczyzną. Celem artykułu było ukazanie wyjątkowości nauczania św. Jana Chryzostoma na temat roli kobiety w rodzinie chrześcijańskiej. Ta wyjątkowość przejawiała się w docenianiu wartości żony i matki jako współodpowiedzialnej za wychowanie dzieci i mającej swój aktywny udział w kształtowaniu chrześcijańskiego charakteru rodziny.

Słowa kluczowe: Jan Chryzostom, kobieta, żona, rodzina

\section{The Role of a Woman in the Christian Family according to John Chrysostom}

In the article the views of one of the greatest early Christian preachers on the role of women in marriage and the family are portrayed. In this work the views of Chrysostom are discussed, which distinguishes him among other Church fathers.

In the first part of the article the cultural context of the doctrine of the Bishop of Constantinople is shown. It depids how the role of women in the Greco-Roman antiquity culture, as well as in Judaism and the doctrine of Paul of Tarsus was considered.

In the second part Chrysostomos point of view on the woman as a wife and mother is depicted. In the third part the relationship between woman and man is discussed.

The aim of this article is to show the peculiarity of St. John Chrysostom's views on the role of women in the Christian family. This peculiarity is that the role of the wife and the mother is appreciated and that the woman is seen as responsible for the education of children and that she is actively involved in shaping the Christian character of the family.

Keywords: John Chrysostom, woman, wife, family

\section{Bibliografia}

Bober A., Rodzina kościołem domowym według św. Jana Chryzostoma, „Vox Patrum” 5 (1985) z. 8-9, s. 193-199. 
Eckmann A., Starożytna rodzina grecka i rzymska, ,Vox Patrum” 5 (1985) z. 8-9, s. 29-49. Historia wychowania, t. 1, red. Ł. Kurdybach, Warszawa 1965.

Jan Chryzostom, Dialogi o kapłaństwie, przekł. W. Kania, Kraków 1992.

Jan Chryzostom, Homilia 20 na List do Efezjan, w: Jan Chryzostom, O małżeństwie, wychowaniu dzieci i ascezie, przekł. W. Kania, Kraków 2002, s. 47-69.

Jan Chryzostom, Homilie na Ewangelię według św. Mateusza - cz. 1 Homilie 1-40, Kraków 2002.

Jan Chryzostom, Homilie na Księgę Rodzaju, Kraków 2008.

Jundziłł J., Praktyka i teoria wychowania w rodzinie w pismach Seneki, Epikteta i Marka Aureliusza, „Vox Patrum” 5 (1985), z. 8-9, s. 51-62.

Jurewicz O., Winniczuk L., Starożytni Grecy i Rzymianie w życiu prywatnym i państwowym, Warszawa 1968.

Jurkiewicz J., „Mater Familias” w nauczaniu św. Jana Chryzostoma, „Vox Patrum” 29 (2009) t. 53-54, s. 223-231.

Kałabun A., Turia rzymskim symbolem miłości i wierności małżeńskiej, „Vox Patrum” 5 (1985), z. 8-9, s. 75-80.

Kania W., Pierwsza rodzinna katecheza domowa w ujęciu św. Jana Chryzostoma, „Vox Patrum" 5 (1985), z. 8-9, s. 215-222.

Katolicki komentarz biblijny, red. R. E. Brown, J. A. Fitzmyer, R. E. Murphy, przekł. K. Bardski, Warszawa 2001.

Krykowski J., Nauka o małżeństwie, rodzinie i wychowaniu, w: Jan Chryzostom, o matżenstwie, wychowaniu dzieci i ascezie, Kraków 2002, s. 17-40.

Kudasiewicz J., Mężowie miłujcie żony, jak Chrystus umiłował Kościół (Ef 5, 21-33), „Vox Patrum" 5 (1985), z. 8-9, s. 81-88.

Kułaczkowski J., Biblijne zasady wychowania rodzinnego w świetle Mądrości Syracha, Rzeszów 1998.

Pałubicki W., Iluk J., Małżeństwo i rodzina w dawnym judaizmie i starożytnym chrześcijaństwie, Gdańsk 1995.

Szczur P., Problematyka społeczna w późnoantycznej Antiochii: na podstawie nauczania homiletycznego Jana Chryzostoma, Lublin 2008.

Sztafrowski E., Chrześcijańskie małżeństwo, Warszawa 1985.

Winniczuk L., Ludzie, zwyczaje, obyczaje starożytnej Grecji i Rzymu, cz. 2, Warszawa 1985.

Wójtowicz H., Zadania rodziny chrześcijańskiej w nauczaniu św. Jan Chryzostoma, „Vox Patrum" 5 (1985), z. 8-9, s. 201-214. 